\title{
Modulation of the Axonal Microtubule Cytoskeleton by Myelinating Schwann Cells
}

\author{
Laura L. Kirkpatrick and Scott T. Brady \\ Department of Cell Biology and Neuroscience, University of Texas Southwestern Medical Center, Dallas, Texas 75235
}

\begin{abstract}
The Trembler PNS myelin-deficient mutant mouse offers a unique model for the study of axon-glial interactions. Previous work in our laboratory on Trembler mouse sciatic nerve established that myelinating Schwann cells exert a profound effect on the underlying neuronal cytoskeleton. Demyelinated axon segments exhibited decreases in the rate of slow axonal transport, axonal caliber, and neurofilament phosphorylation, as well as increases in neurofilament density. The present study considers effects on the microtubule cytoskeleton. At least two aspects of the microtubule cytoskeleton in Trembler PNS axons were altered by demyelination. First, the stability of the Trembler axonal microtubule cytoskeleton is decreased, as measured by decreased levels of insoluble tubulin (Sahenk and Brady, 1987). Second, the composition and phosphorylation of axonal microtubuleassociated proteins, including tau, MAP 1A, and MAP 1B, are changed in Trembler demyelinated nerves. Further, the fraction of axonal tubulin moving at slow component $b$ rates was increased (de Waegh and Brady 1990, 1991). These results provide further evidence that cell-cell interactions between myelinating glia and their underlying axons extend beyond a structural role, actively influencing biochemical and physiological properties of the axon.
\end{abstract}

[Key words: axonal transport, microtubules, myelination, demyelination, cytoskeleton, Trembler mouse, tubulin, microtubule-associated proteins, phosphorylation]

The cytoskeleton represents a dynamic and complex component of the neuron, one that plays a critical role in development and maintenance of the nervous system. To fulfill that role, microtubules (MTs), neurofilaments (NFs), and actin microfilaments exist in a variety of specialized forms that help establish functional domains within neurons while providing the basic structural framework for neurons (Brady, 1988). These specializations include not only distinct genetic isoforms that are expressed differentially during development and maturation, but posttranslationally modified isoforms.

The genetic and biochemical diversity of neuronal MTs are particularly striking. Not only do multiple genes exist for both

\footnotetext{
Received Feb. 18, 1994; revised May 18, 1994; accepted May 26, 1994.

We thank Drs. Skip Binder, George Bloom, and Virginia M.-Y. Lee for generous gifts of monoclonal antibodies. The research described in this report was supported in part by grants from the National Institutes of Health (NS23868 and NS23320), the Council for Tobacco Research (3258), the Welch Foundation (1237), and the Muscular Dystrophy Association.

Correspondence should be addressed to Dr. Scott Brady, Department of Cell Biology and Neuroscience, University of Texas Southwestern Medical Center, 5323 Harry Hines Boulevard, Dallas, TX 75235-9111.

Copyright (c) 1994 Society for Neuroscience 0270-6474/94/147440-11\$05.00/0
}

$\alpha$ - and $\beta$-tubulins (Lewis et al., 1985; Sullivan, 1988; Luduena, 1993), but a variety of posttranslational modifications exist (e.g., see Brady et al., 1984; Gard and Kirschner, 1985; Murata et al., 1986; Khawaja et al., 1988; Black et al., 1989; Edde et al., 1990). Further, heterogeneity is created in neuronal MTs through binding of various microtubule-associated proteins (MAPs) to different populations of MTs (Olmsted, 1986; Matus, 1988). The functional significance of this diversity is not well understood, but may be responsible for differences in MT assembly and stability properties.

A particularly stable subset of MTs exist as short segments within axonal MTs (Sahenk and Brady, 1987; Baas and Black, 1990). These stable MT segments are resistant to depolymerization by antimitotic drugs, cold, and calcium. Based on this characteristic, an extraction protocol was developed to quantitate the amount of cold-insoluble tubulin in axonal MTs (Brady et al., 1984). Such stable domains in MTs may serve to regulate the axonal cytoskeleton by nucleating and organizing MTs. There are indications that levels of cold-insoluble tubulin corrclate with axonal plasticity (Brady, 1988). However, the biochemical basis of MT stability remains under investigation and little has been known about factors that determine the amount of stable MTs in axons.

Recent work has suggested that biochemical specializations of the neuronal cytoskeleton can be modulated by the local environment (Brady, 1992; de Waegh et al., 1992). For many neurons, this local microenvironment is largely determined by myelinating glial cells (Schwann cells or oligodendrocytes) and compact myelin sheaths. In the Trembler PNS myelin-deficient mutant mouse, Schwann cells cannot maintain compact myelin (Aguayo et al., 1977), leading to disruption of axon-glia interactions. Axons surrounded by Trembler Schwann cells have increased NF density accompanied by decreases in slow axonal transport rates, axonal caliber, and NF phosphorylation (de Waegh and Brady, 1990, 1991; de Waegh et al., 1992). This demonstrated that myelinating Schwann cclls affcct axonal neurofilaments by changing posttranslational modifications of their constituent proteins. Such effects are spatially restricted and occurred in local regions of the axon when segments of Trembler sciatic nerve were grafted into normal mouse nerve (de Waegh and Brady, 1991; de Waegh et al., 1992). The present study was designed to extend these observations, and characterize alterations in the MT cytoskeleton caused by demyelination in the Trembler mutant.

Two aspects of the axonal MT cytoskeleton were considered. First, the effect of demyelination on levels of cold-insoluble MTs was determined by analyzing tubulin transported in Trembler mouse sciatic nerve axons. Second, quantitative immunoblots were used to characterize properties of MAPs associated with 
axonal MTs in demyelinated Trembler ncurons. Cold-insoluble tubulin levels were significantly decreased in Trembler peripheral nerves, while both the amount and phosphorylation state of axonal MAPs were altered. These observations demonstrate that myelinating Schwann cells modulate characteristics of both the MT and NF cytoskeleton in axons.

\section{Materials and Methods}

Unless otherwise noted, all materials were obtained from Sigma (St. Louis, MO). The mice used in these studies were Trembler C57BL/6J $\mathrm{Tr}^{\mathrm{J}}$ and their control siblings, which were obtained from Jackson Laboratory (Bar Harbor, Maine). Animals were kept in a sterile environment and fed sterile food and water. Both male and female mice, 2-4 months old, were used in all experiments.

Cold/calcium tubulin fractionation. Proteins carried by slow axonal transport in Trembler and control mouse sciatic nerve sensory fibers were labeled as described previously (de Waegh and Brady, 1991; de Waegh et al., 1992). Briefly, aliquots containing $0.5 \mathrm{mCi}$ of ${ }^{35} \mathrm{~S}-\mathrm{methi}-$ onine (Trans ${ }^{35} \mathrm{~S}$-label, ICN, Irvine, CA) were injected into the right L5 DRG of anesthetized mice. After the appropriate injection-sacrifice interval (ISI), 6-7 d for $\mathrm{SCb}$ and $10-14 \mathrm{~d}$ for $\mathrm{SCa}$, each mouse was killed and the sciatic nerve removed for analysis. A $1 \mathrm{~cm}$ segment of the sciatic nerve, $8-18 \mathrm{~mm}$ from the DRG, containing the labeled slow component of interest was excised and immediately subjected to a cold/ calcium fractionation procedure (Brady et al., 1984). Nerve samples were homogenized in ice-cold MTG buffer (1 mM EGTA, $0.5 \mathrm{mM} \mathrm{MgCl}_{2}$, $1 \mathrm{~mm}$ GTP in $0.1 \mathrm{M}$ MES, pH 6.8), incubated on ice for $30 \mathrm{~min}$, and then centrifuged at $130,000 \times g$ in a Beckman TL100 tabletop ultracentrifuge for $30 \mathrm{~min}$ at $4^{\circ} \mathrm{C}$. Depolymerized and cold-soluble proteins remain in the supernatant (S1), while polymerized and cold-insoluble proteins pellet. This initial pellet (P1) was resuspended in CMTG buffer (5 mM $\mathrm{CaCl}_{2}, 0.5 \mathrm{~mm} \mathrm{MgCl}, 1 \mathrm{~mm}$ GTP in 0.1 M MES, pH 6.8 ), incubated $30 \mathrm{~min}$ at room temperature, and centrifuged for $30 \mathrm{~min}$ at $15^{\circ} \mathrm{C}$ as above. This second supernatant (S2) consists of calcium-soluble mlaterial, and the final pellet (P2) contains cold/calcium-insoluble proteins. The $S 1$ and $S 2$ fractions were TCA precipitated, ethanol washed, and dried. The $P 2$ pellet and the S1 and S2 TCA pellets were resuspended in $200 \mu \mathrm{l}$ of BUST ( $2 \% \beta$-mercaptoethanol, $8 \mathrm{M}$ urea, $1 \% \mathrm{SDS}, 0.1 \mathrm{M}$ Tris, and $0.02 \%$ phenol red). Equal volumes of each fraction were used for comparison by SDS-PAGE and fluorography on 4-16\% gradient gels. The amount of radioactivity incorporated into specific proteins was quantitated by excising and solubilizing appropriate bands from the gel and counting in a liquid scintillation counter. Two to six mice of each type (control and Trembler) were used for analysis at each ISI.

Immunoblot sample preparation. To obtain neural tissues for quantitativc immunoblot experiments, 2-4-month-old Trembler and control mice were sacrificed under ether anesthesia. Sciatic and optic nerves were removed bilaterally from each mouse. The freshly removed tissue was immediately homogenized in $1 \% \mathrm{SDS} / 10 \%$ glycerol, and then boiled for $5 \mathrm{~min}$. An aliquot of each sample was removed and used for protein assay (BCA Protein Assay, Pierce, Rockford, IL). The remainder of each sample was mixed with an equal volume of Laemmli sample buffer $(2 \%$ SDS, $5 \% \mathrm{BME}, 10 \%$ glycerol in $0.06 \mathrm{M}$ Tris), frozen, and stored at $-80^{\circ} \mathrm{C}$ until use. For comparisons with cycled microtubule protein, MTs were isolated with the aid of taxol from whole rat and mouse brain as previously described (Vallee, 1982), and stored in aliquots at $-80^{\circ} \mathrm{C}$ until use.

Electrophoretic techniques and quantitative immunoblotting. Samples containing equal amounts of total protein were taken from control and Trcmblcr sciatic and optic nerves, and then separated adjacent to lanes of brain MTs using 4-16\% (0-6 M urea) gradient gels for tau analyses or $4 \%$ ( $2 \mathrm{~m}$ urea) straight gels for HMW MAP analyses by SDS-PAGE. After electrophoresis, the gels were silver stained (Blum et al., 1987) or used for immunoblots. Immunoblotting was done essentially as described previously (de Waegh et al., 1992), with a few modifications. Briefly, proteins were transferred to Immobilon-P transfer membrane (Millipore, Bedford, MA) for 16-20 hr at $25 \mathrm{~V}$ in $10 \mathrm{~mm}$ CAPS buffer, pH 11 (Gillespie and Hudspeth, 1991). Blots were blocked for $2 \mathrm{hr}$ in BBS (100 mm boric acid, $25 \mathrm{~mm}$ sodium borate, $75 \mathrm{~mm} \mathrm{NaCl}, \mathrm{pH} 8.2$ ) supplemented with $5 \%$ Carnation nonfat dry milk, and then incubated overnight with primary antibody in the same milk solution. After washing in BBS, blots were incubated successively in rabbit anti-mouse IgG or IgM (Jackson Immunoresearch, West Grove PA) for $3 \mathrm{hr}$, and then
${ }^{174}$ I protcin A (Amersham, Arlington IIeights, IL) for $3 \mathrm{hr}$. The blots were extensively washed, dried, and exposed to Phosphorimager screens (Molecular Dynamics, Sunnyvale, CA).

To quantitate differences in control and Trembler sciatic nerve MAPs, immunoblots were analyzed with the IMAGEQUANT software package on a Molecular Dynamics Phosphorimager. In brief, a box was drawn around each immunoreactive band and the radioactivity bound in that region determined. The radioactivity in each MAP band was normalized to the amount of $\beta$-tubulin stained in the same sample to control for possible protein-loading differences. Similarly, to control for variability between blots, all statistical analyses were done using DATA DESK 4.1 statistical analysis software (Data Description, Inc., Ithaca, NY) on paired samples from a single blot and a single experiment. Quantitation of tau and HMW MAP levels used three to five pairs of mice.

Monoclonal antibodies used included (1) MAP 1A-2 (Bloom et al., 1984) ascites fluid at 1:100 dilution; (2) MAP 1B-4 (Bloom et al., 1985) tissue culture media used straight; (3) MAP 1B-3 (Luca et al., 1986), a monoclonal antibody that recognizes a phosphorylated epitope on both MAP $1 \mathrm{~A}$ and $1 \mathrm{~B}$ and cross-reacts with NFH and NFM, ascites fluid at 1:1000 dilution; (4) Tau-1 (Binder et al., 1985), which recognizes a tau epitope often masked by phosphorylation in neurons, tissue culture media used straight; (5) Tau-46 (Kosik et al., 1989), which recognizes the C-terminal of tau and cross-reacts with MAP 2, ascites fluid at 1:1000; and (5) a total $\beta$-tubulin monoclonal antibody (Amersham) at 1:2000. The HMW MAP antibodies were generous gifts from Dr. George Bloom (University of Texas Southwestern Medical Center, Dallas, TX), and the tau antibodies were gifts from Drs. Skip Binder (Chicago, IL) and Virginia Lee (University of Pennsylvania, Philadelphia, PA).

\section{Results}

Since our earlier studies with Trembler mice demonstrated that myelinating Schwann cells exerted a profound influence on slow axonal transport and the NF cytoskeleton, biochemical characteristics of MTs from Trembler and control nerves were evaluated. First, the fraction of axonal MTs that were cold insoluble (stable M I's) was measured in Trembler and control nerves. The cold/calcium fractionation assay separated MTs and other protcins on the basis of their depolymcrization and solubility characteristics. Starting with a nerve homogenate, three fractions were generated: S1, S2, and P2. The S1 fraction contained depolymerized MTs and other cold-soluble proteins. The S2 fraction consisted of calcium-soluble, cold-insoluble proteins, while the P2 fraction was the cold/calcium-insoluble fraction. P2 contained cold-insoluble MTs and NFs. The axonal transport paradigm (Brady, 1985) was used to label proteins carried down DRG sensory neurons by slow axonal transport, thereby restricting analyses to neuronal tubulin in Trembler and control mouse sciatic nerves. By injecting ${ }^{35} \mathrm{~S}$-methionine into the $\mathrm{L} 5$ DRG of a mouse, axonal proteins were labeled specifically and could be studied without contamination of proteins from glial and other cell types.

Since in PNS neurons tubulin is carried in both slow axonal transport components, the levels of cold-insoluble MTs in SCa and $\mathrm{SCb}$ were analyzed scparatcly. Scgments of sciatic nerve contained only SCa- or SCb-labeled proteins at any one time depending on the injection-sacrifice interval (ISI). Based on slow axonal transport rates determined previously for control and Trembler mouse sciatic nerve (de Waegh and Brady, 1990), a 6-7 d ISI provided labeled SCb proteins in a $1 \mathrm{~cm}$ segment 8$18 \mathrm{~mm}$ from the DRG. Similarly, a 10-14 d ISI labeled SCa proteins in the same segment. Thus, a $1 \mathrm{~cm}$ segment of the sciatic nerve at the same distance from the ganglia was used as the tissue sample for all analyses, and levels of cold-insoluble MTs in SCa and SCb were characterized individually.

Examples of fluorographs from typical experiments are shown in Figure 1. As reported previously for rat (Brady and Black, 1986), there appeared to be comparable amounts of tubulin in 
A. SCa

CONTROL

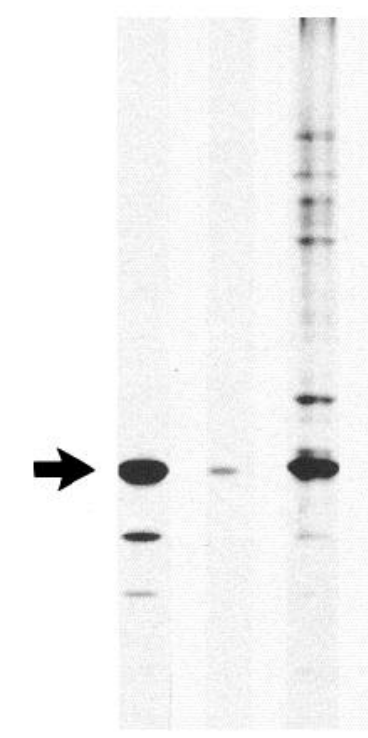

S1 S2 P2
TREMBLER

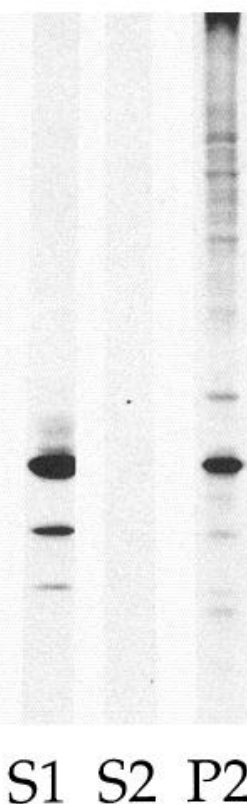

B. $\mathrm{SCb}$

CONTROL

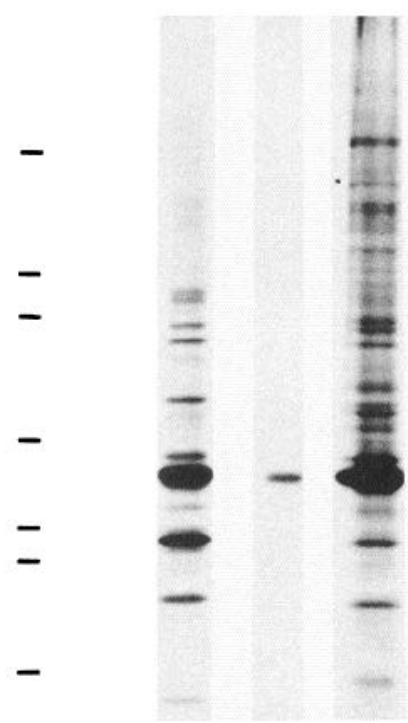

S1 S2 P2

\section{TREMBLER}

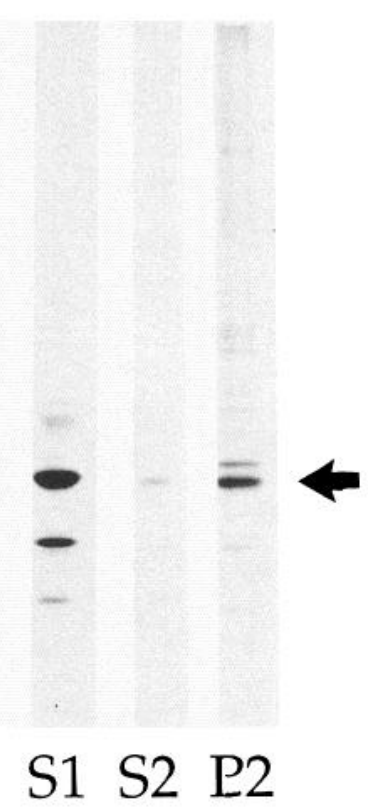

Figure 1. Cold/calcium fractionation of control and Trembler mouse sciatic nerve: fluorographs from typical experiments containing SCa- $(A)$ or $\mathrm{SCb}-(B)$ radiolabeled proteins. Sciatic nerve proteins were labeled by injection of mouse dorsal root ganglion sensory neurons with ${ }^{35} \mathrm{~S}-\mathrm{methionine}$ and examined in the nerve after the appropriate injection-sacrifice intervals. Sciatic nerves were removed and homogenized in MTG buffer on ice, and then centrifuged as described in the text to generate three fractions: $\mathrm{S} 1$ was the cold-soluble fraction, $\mathrm{S} 2 \mathrm{was}$ the cold-insoluble but $\mathrm{Ca}^{2+}$-soluble fraction, and P2 was the cold- and $\mathrm{Ca}^{2+}$-insoluble fraction. The position of tubulin is indicated by an arrow. The amount of S1 tubulin may be compared to the amount of P2 tubulin for control and mutant mouse nerves. In control sciatic nerve, the levels of S1 and P2 tubulin are similar, while in Trembler sciatic nerve the fraction of tubulin in S1 was increased and the amount of tubulin in P2 was correspondingly decreased. This was true for both SCa- and SCb-labeled tubulin. Molecular weight markers used are 180, 116, 84, 58, 48.5, 37, and 27 kDa.

control S1 and P2 fractions. In contrast, the Trembler S1 fraction appeared to have much more tubulin than the $\mathrm{P} 2$ fraction. This difference could be seen for both $\mathrm{SCa}$ and $\mathrm{SCb}$ tubulin, and suggested that there was a decrease in the number of cold-insoluble MTs in Trembler sciatic nerve sensory neurons. Qualitatively, no gross changes in the fractionation of other proteins between Trembler and control nerves were seen.

To quantitate these differences, fluorographs were used as templates to excise appropriate bands from each gel. Gel slices were solubilized and the amount of incorporated radioactivity in each band determined by liquid scintillation counting. To facilitate comparisons between Trembler and control nerves, we totaled the amount of radioactivity present in the tubulin bands for S1, S2, and P2. Each fraction was expressed as a percentage of the total. As seen in Figure 2, when control nerve SCa-labeled MTs were fractionated, $44 \%$ are cold soluble (S1) and $45 \%$ were cold insoluble (P2). In contrast, when Trembler nerve SCalabeled MTs were fractionated, $58 \%$ were cold soluble (S1) and $30 \%$ were cold insoluble (P2). This was a significant decrease in the amount of cold-insoluble MTs in the Trembler nerve ( $p$ $<0.001$, Student's $t$ test). Similar results were found for both $\mathrm{SCa}$ - and SCb-carried MTs.

To control for the possibility that the Trembler tubulin fractionation pattern was not specific for tubulin, radioactivity incorporated into NFs (SCa) and actin ( $\mathrm{SCb}$ ) was also quantitated in each fraction. As seen in Figure 2, there were no significant differences in the distribution of these proteins between fractions of Trembler and control nerves. To determine whether decreases in cold-insoluble tubulin levels were specific for axons surrounded by Schwann cells, labeled optic nerve proteins after an ISI appropriate for labeling $\mathrm{SCa}$ were subjected to the same fractionation. As can be seen in Figure 3, there is no difference in the fractionation of MTs between Trembler and control optic nerves. There is no tubulin carried in $\mathrm{SCb}$ in CNS neurons (McQuarrie et al., 1986; Oblinger et al., 1987). This demonstrated that the changes seen in Trembler sciatic nerve MTs are PNS specific, as is the Trembler mutation (Suter et al., 1992).

The experiments described above demonstrated that Trembler demyelination affects the stability of the MT cytoskeleton. Differing levels of stability represent one aspect of neuronal MT heterogeneity; another is the composition of MAPs binding to MTs. To characterize differences between MAPs in Trembler and control MTs, nerve segments were analyzed by quantitative immunoblotting. MAPs in different nerves or subcellular domains can also differ in phosphorylation state. In light of our previous studies showing that demyelination of Trembler sciatic nerve axons causes NF dephosphorylation (de Waegh and Brady, 1991; de Waegh et al., 1992), antibodies that could distinguish different phosphoforms of MAPs were of particular interest.

The first MAPs to be examined were the taus. Tau exists in multiple forms in various parts of the nervous system. In brain 


\section{A. SCa Tubulin}

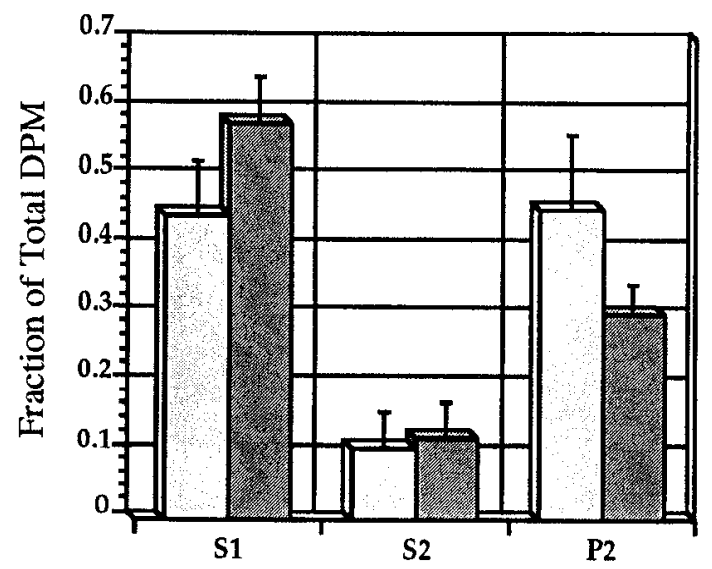

\section{B. SCa NFM}

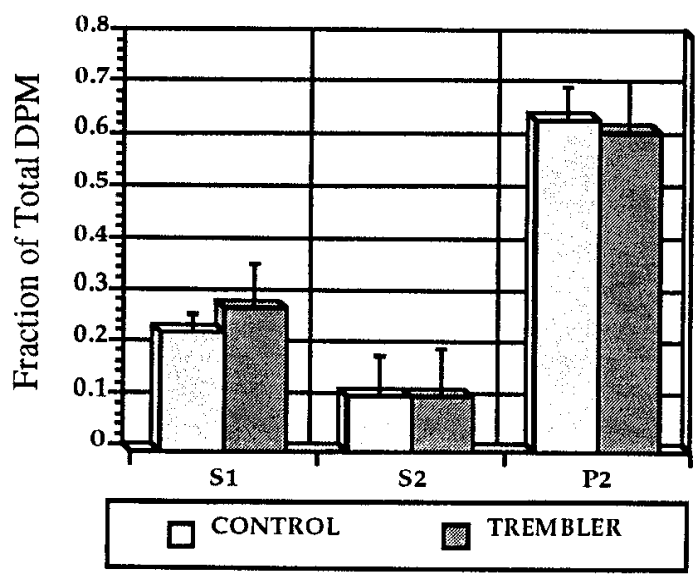

C. SCb Tubulin

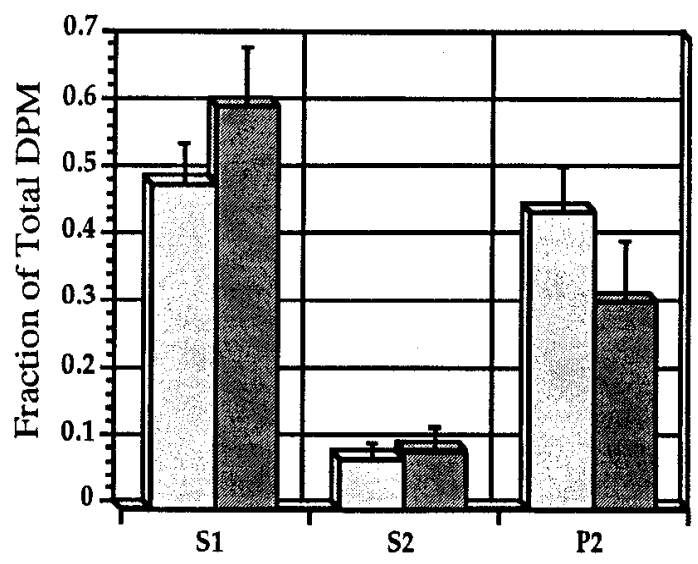

D. SCb Actin

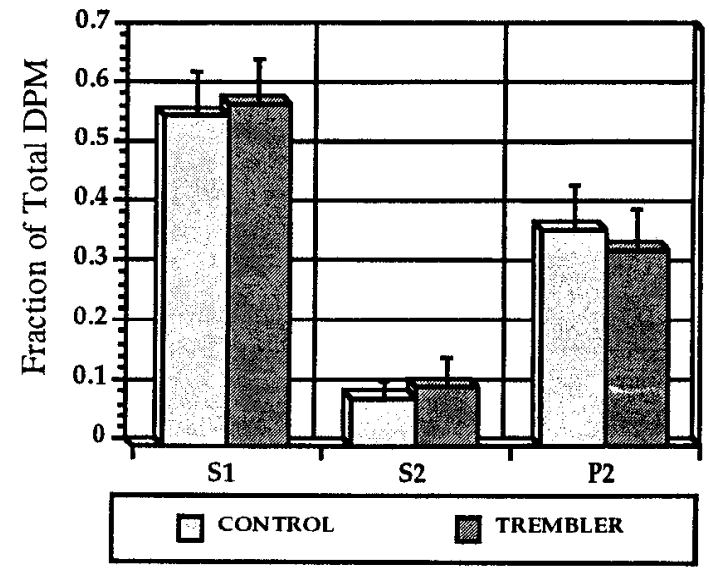

Figure 2. The amount of cold-insoluble tubulin in Trembler sciatic nerve was significantly decreased. Fluorographs were used as templates to excise tubulin bands from each gel and the amount of incorporated radioactivity was counted. Values for S1, S2, and P2 were totaled for each control and Trembler expcriment, and then cxpressed as a percentage of the total labeled tubulin. $A-D$ are histograms showing mean \pm SD. $A$ and $C$ represent the fractionation of SCa- and SCb-labeled MTs, respectively. In both cases, there was a significant decrease in the amount of coldinsoluble tubulin (P2) in Trembler sciatic nerves (Student's $t$ test: $\mathrm{SCa}$, significantly different at $p<0.001$; $\mathrm{SCb}, p<0.01$ ). The amount of tubulin in the soluble fraction (S1) was correspondingly increased in Trembler nerves, but there were no significant differences between Trembler and control in the amount of tubulin in the S2 fraction. In contrast to changes seen in tubulin fractionation, radioactivity incorporated into NFM (B) and actin $(D)$ was also determined for each control and Trembler sciatic nerve fraction. There were no significant differences between Trembler and control in the distribution of these two polypeptides.

extracts, tau composition is primarily low-molecular-weight (LMW) tau, consisting of five or six proteins ranging in size from 50 to $70 \mathrm{kDa}$ on SDS gels (Cleveland et al., 1977). These proteins copurify with tubulin during assembly-disassembly cycles and can promote MT assembly and stabilization (Matus, 1988). A mid-molecular-weight (MMW) form of tau with an apparent molecular weight of 90-100 kDa (Taleghany and $\mathrm{Ob}-$ linger, 1992) and a high-molecular-weight (HMW) tau (110$120 \mathrm{kDa}$ ) (Drubin and Kirschner, 1986; Georgieff et al., 1991; Oblinger et al., 1991; Taleghany and Oblinger, 1992) have been also been described in some preparations. Additional heterogeneity in taus results from phosphorylation of tau at one or more sites.

To characterize differences in tau abundance and phosphorylation between Trembler and control sciatic nerve, two monoclonal antibodies were used: Tau-46, which recognizes the C-terminal of tau (Kosik et al., 1989), and Tau-1, which recognizes an epitope in the MT-binding domain of tau that may be masked by phosphorylation in neurons (Binder et al., 1985). Tau-46 staining was used as a measure of total tau protein present. Tau46 is directed against a region of lau that appears to be present in all known alternatively spliced forms of tau in mouse (Lee et al., 1988) and has not been reported to be subject to phosphorylation in normal brains. Based on the available information, we have used this antibody as an estimate of total tau in the nerve, but direct measures of tau synthesis in the cell bodies will be needed to determine whether the amount of total tau is changed by demyelination. Tau- 1 staining was used as a measure of phosphorylation at a particular epitope. Since tau can be phosphorylated at a number of other sites, these experiments can only evaluate the effect of demyelination on phosphorylation at the Tau-1 site.

Figure 4 shows a silver-stained pattern of samples used for immunoblots, and representative blots of those samples using two tau mAbs. To facilitate identification of tau proteins in mouse nerve samples, control and Trembler nerve samples were 


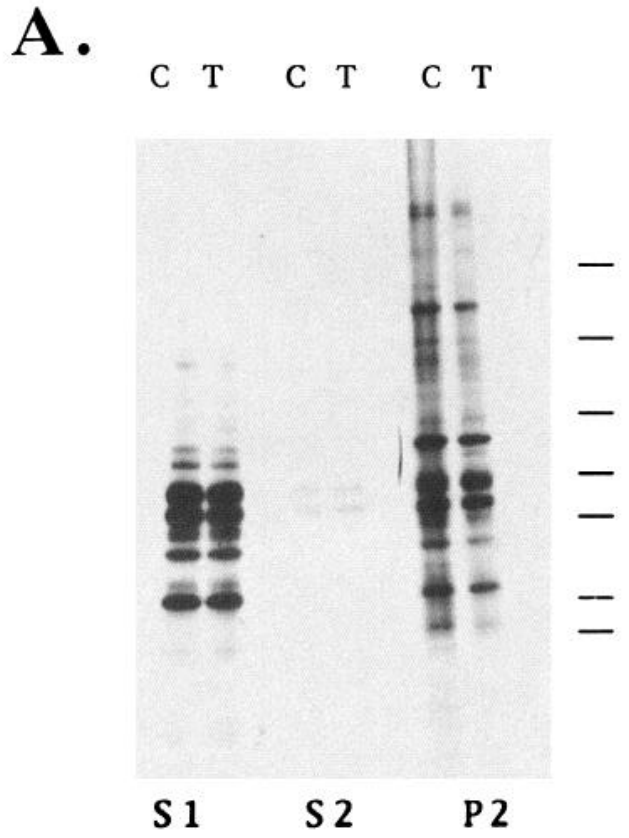

B.

\section{SCa Tubulin}

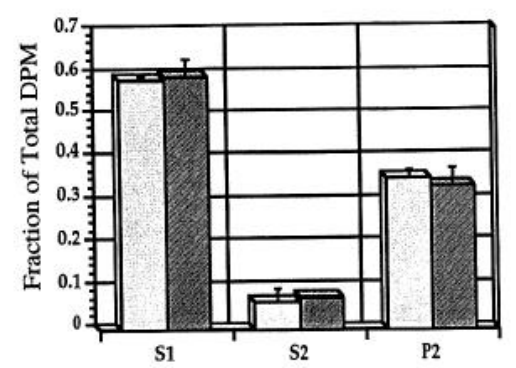

SCa NFM

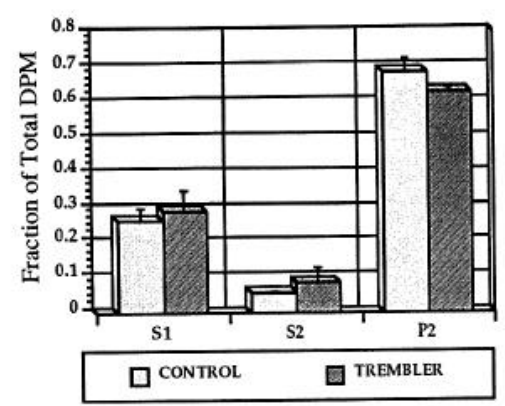

Figure 3. Cold/calcium fractionation of control and Trembler mouse optic nerve. To verify that decreases in cold-insoluble tubulin seen in Trembler sciatic nerve were specific for axons surrounded by Trembler mutant Schwann cells, optic nerve MTs were also fractionated as described in the text. $A$, Fluorograph of fractionated SCa-labeled MTs from control $(C)$ and Trembler $(T)$ mouse optic nerve. Molecular weight markers: $180,116,84,58,48.5,36.5,26.6 \mathrm{kDa}$. $B$, Determination of tubulin and NFM radioactivity in each fraction as described previously. Unlike the situation found in sciatic nerve, there were no differences seen between control and Trembler mice in the fractionation of MTs from optic nerves. run adjacent to lanes of rat and mouse brain MT proteins. Figure $4 B$ shows these MT samples blotted with Tau- 46 and Tau-1. Both antibodies recognize similar populations of HMW and LMW taus, although there are molecular weight differences between rat and mouse. Tau-46 also cross-reacts with MAP 2 (Kosik et al., 1989), although the site of cross-reactive domains on tau and MAP 2 has not been defined.

In mouse nerve samples, HMW, MMW, and LMW taus as well as MAP 2 were initially identified based on their apparent molecular weight. Both Tau-46 and Tau-1 stain a band at 115$120 \mathrm{kDa}$ that corresponds to $\mathrm{HMW}$ tau. The $110 \mathrm{kDa}$ band stained by both antibodies appears to be the optic nerve-predominant MMW tau, and the bands in the 40-60 kDa range are traditional LMW tau forms. The very-high-molecular-weight $(>300 \mathrm{kDa})$ band in the Tau-46 blot of rat microtubules represents MAP 2, but this HMW MAP was not further analyzed.

Both Tau- 46 and Tau- 1 stained more protein bands in control and Trembler nerve samples than anticipated. Partial proteolysis of tau during extraction may contribute to this pattern, but inclusion of protease inhibitors in homogenization buffers had little effect on tau immunostaining patterns in nerve. Some bands stained in nerve samples but not microtubule preparations by one or both tau mAbs were identifiable. Bands labeled NFH and NFM were identified using NF-specific monoclonal antibodies (data not shown), consistent with previous reports that some tau mAbs cross-react with NF proteins. Since little information is available on tau proteins in mouse (especially those in peripheral nerve), only those bands that reacted with two tau mAbs directed against different tau epitopes and were present in microtubule preparations from mouse brain were identified as tau in this study.

Regardless of whether these immunoreactive species correspond to tau isoforms or to tau-related proteins in mouse, immunoblots permitted a comparison between tau immunoreactivity in demyelinated and normal nerves. Differences between Trembler and control mouse sciatic nerve tau immunoreactivity are apparent in Figure $4 C$. For quantitative studies, the radioactivity in each tau band was normalized to the amount of $\beta$-tubulin in the same sample to control for possible proteinloading differences. Based on quantitation of Tau- 46 immunoblots, there was a decreased amount of HMW tau immunoreactivity, but more LMW tau immunoreactivity, in Trembler than control sciatic nerves $(p=0.015$ and $p \leq 0.001$, respectively, $t$ test using paired samples). Since Tau- 46 is insensitive to tau phosphorylation, these data indicate that there may be quantitative differences in the total amount of HMW and LMW tau MAPs in Trembler axons.

Tau-46 and Tau-1 produce qualitatively similar, but not identical, patterns for Trembler and control sciatic nerve. Since Tau- 1 recognizes one of several tau phosphorylation sites only when that site is dephosphorylated, differences in staining with the two mAbs may reflect differences in phosphorylation. Tau-1 immunoreactivity is higher for LMW tau in Trembler than in control nerves ( $p=0.0002$ with $t$ test using paired samples), but there appears to be more LMW tau in Trembler than in control nerve based on Tau-46 staining. Therefore, differences in Tau-1 staining for LMW tau are likely to reflect differences in level. Similarly, levels of Tau-1 staining for HMW tau were significantly less in Trembler than in control nerves $(P=0.0003)$. Although the level of HMW tau is reduced in Trembler based on Tau-46 staining, the differences seen in Tau-1 staining were more striking, raising the possibility that HMW tau may be 

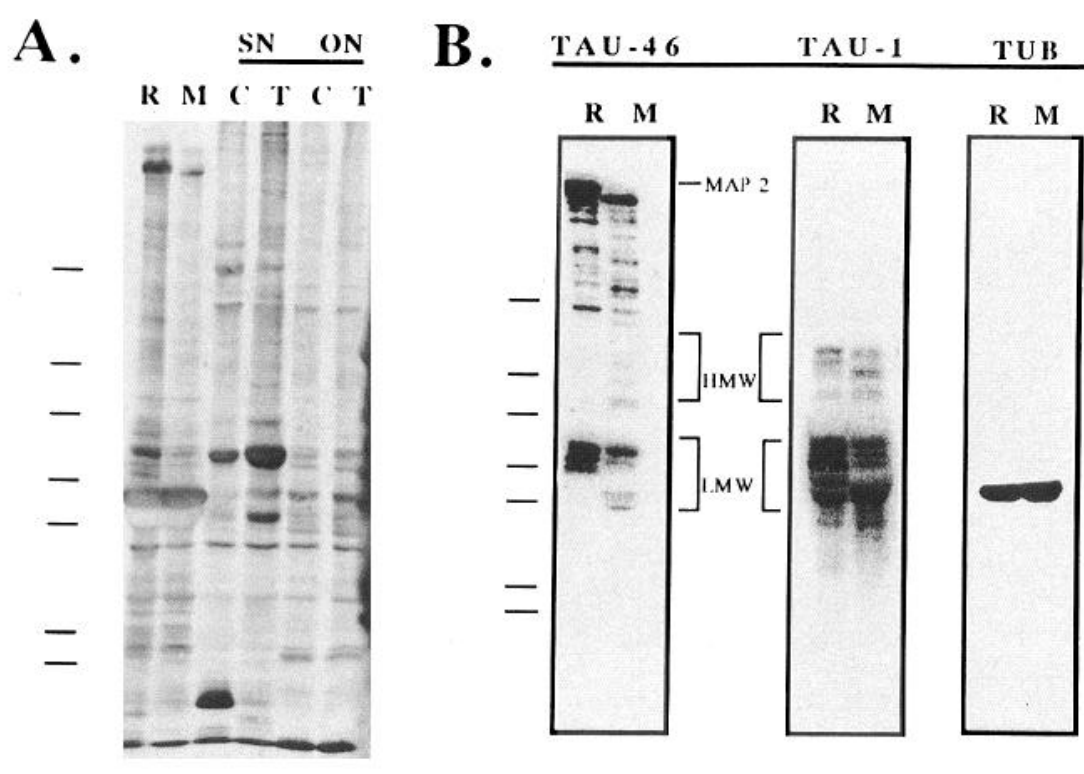

C.

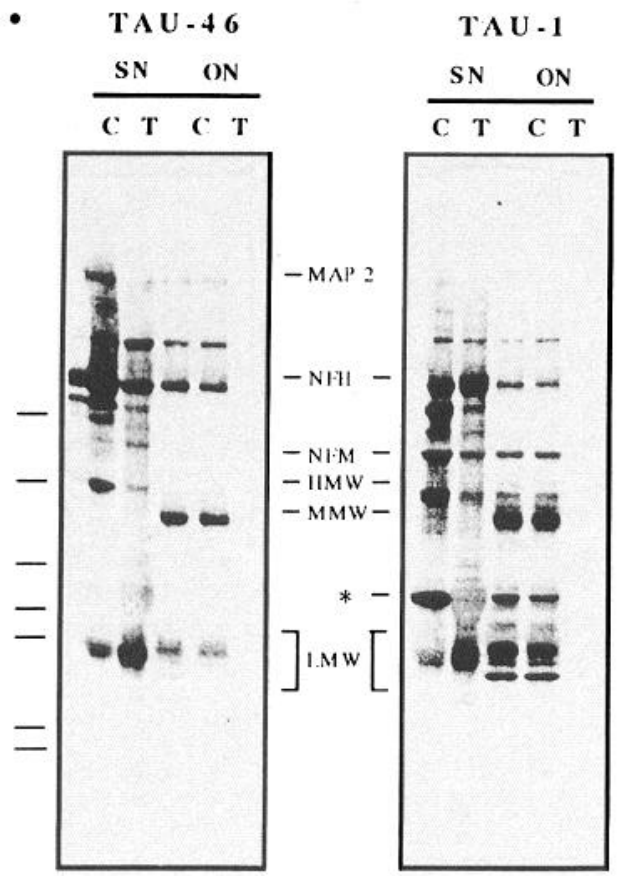

differentially phosphorylated. No effort was made to calculate absolute amounts of tau protein present in Trembler and control nerves, but these experiments demonstrate differences between myelinated and demyelinated nerves in both the relative amounts and phosphorylation state of tau proteins.

One additional polypeptide exhibited a significant difference in Tau-1 staining for Trembler and control nerves. A $60 \mathrm{kDa}$ band (* in Fig. $4 C$ ) was stained by Tau-1, but was not stained appreciably with Tau-46. This band did not appear in all immunoblots and was treated separately from the rest of LMW tau for analysis, because the absence of Tau-46 staining precluded positive identification of this polypeptide as a tau protein. Immunoreactivity corresponding to this $60 \mathrm{kDa}$ band was at a high level in many control nerves, but greatly reduced in Trembler. Since Tau-1 recognizes a dephosphorylated epitope,
Figure 4. Immunoblot detection of tau proteins. $A$, Silver stain of samples used for analysis: rat $(R)$ and mouse $(M)$ brain MTs, prepared with the aid of taxol, 15 $\mu \mathrm{g}$ each; control $(C)$ and Trembler $(T)$ mouse sciatic $(S N), 15 \mu \mathrm{g}$ each, and optic $(O N)$ nerve samples, $10 \mu \mathrm{g}$ each. $B$, PhosphorImager image of immunoblots of rat and mouse brain MTs with three mAbs: Tau-46, which recognizes the C-terminal of tau; Tau-1, which recognizes a phosphorylation-sensitive epitope in the tau MT-binding region; and a commercially available anti- $\beta$-tubulin antibody. Though there were variations between rat and mouse, the antibodies recognize similar populations of HMW and LMW tau proteins. $C$, PhosphorImager image of immunoblots of control and Trembler nerves with the same three mAbs. Thirty micrograms of each SN sample and $10 \mu \mathrm{g}$ of each ON sample were used. Differences between control and Trembler can be seen both in the amount and phosphorylation of HMW and LMW tau proteins for sciatic nerves, but not for optic nerves. Asterisk indicates a $60 \mathrm{kDa}$ band that did not stain with Tau-46 and so was not counted as LMW tau for further analysis. Molecular weight markers: $180,116,84,58,48.5,36.5$, $26.6 \mathrm{kDa}$. this polypeptide was either much more highly phosphorylated at a Tau-1-like epitope in Trembler nerves, or absent from Trembler altogether.

To determine whether differences in tau protein were systemic or restricted to demyelinated nerves, Trembler and control mouse optic nerve immunoblots were probed with Tau-46 and Tau-1. As seen in Figure $4 C$, there were no qualitative differences in tau staining patterns between the optic nerves of Trembler and control mice for either mAb. Quantitative analyses of optic nerve immunoblots confirm this observation (data not shown).

Relative amounts of high-molecular-weight (HMW) MAPs were also characterized in immunoblots of Trembler and control sciatic nerves. Traditionally, five polypeptides comprise the HMW MAPs: MAP 1A, 1B, 1C, 2A, and 2B. Figure $6 A$ shows the silver-stained pattern of samples used for analysis of HMW 


\section{Tau Immunoreactivity in Trembler and Control Mouse Sciatic Nerve}

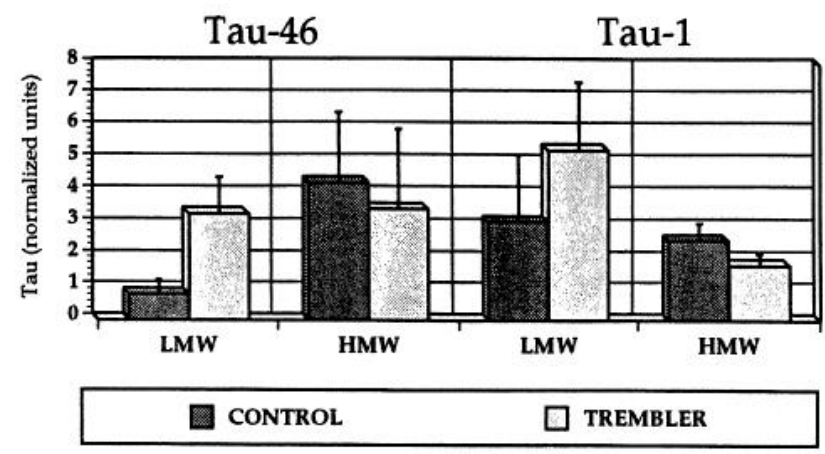

Figure 5. The composition of tau proteins differs in Trembler sciatic nerve. The amount of radioactivity incorporated into each group of tau proteins was determined using IMAGEQUANT software on a Molecular Dynamics PhosphorImager. To control for possible protein-loading differences, values were normalized to the amount of $\beta$-tubulin in the same sample and statistical analyses used paired samples from the same experiment. This histogram represents the sample mean \pm SD for control and Trembler mouse sciatic nerve HMW and LMW tau populations. Using Tau-46, the amount of immunoreactivity against HMW tau was decreased in Trembler relative to control sciatic nerves (different at $p$ $=0.015)$, while immunoreactivity against LMW tau was increased in Trembler (different at $p=0.0001$ ). The amount of immunoreactivity against LMW tau proteins with Tau-1 was increased in Trembler sciatic nerve relative to control (LMW tau significantly different at $p=0.0002$ ), while Tau-1 staining of HMW tau was decreased in Trembler (significant at $p=0: 0003$ ). The increase in dephosphorylated epitopes on tau seen with Tau-1 was due at least in part to differences in protein level, but relative decreases in tau phosphorylation in Trembler nerve may also exist since the magnitude of increase seen with Tau-1 was greater than that seen with Tau-46.

MAPs. Rat and mouse brain MTs prepared with taxol were used as a standard for identifying HMW MAPs. Interestingly, there were notable differences in the HMW MAPs between rat and mouse brain MTs. Most obvious are the differences in MAP 1 mobilities and the absence of a band comigrating with MAP $2 \mathrm{~A}$ in mouse.
Three mAbs were used to investigate the amount and phosphorylation state of MAPs 1A and 1B in Trembler and control sciatic nerves: MAP 1A-2 and MAP 1B-4 recognize these MAPs individually; MAP 1B-3 recognizes a phosphorylated epitope on MAPs $1 \mathrm{~A}$ and $1 \mathrm{~B}$ and also cross-reacts with NFH and NFM. Figure $6 B$ shows the high-molecular-weight region of immunoblots using the three mAbs. In the MAP 1A-2 blot, electrophoretic migration of MAP $1 \mathrm{~A}$ from mouse brain appears slightly faster than rat brain MAP 1A, but MAP 1A from Trembler and control mouse sciatic nerve appears to align well with rat brain MAP 1A. This result suggests that different MAP 1A isoforms may be found in mouse brain and sciatic nerve. Regardless, the amount of total MAP 1A immunoreactivity does not seem to differ between Trembler and control mouse sciatic nerve.

MAP 1B-3 recognized phosphorylated forms of both MAP $1 \mathrm{~A}$ and $1 \mathrm{~B}$. Both phosphorylated MAP $1 \mathrm{~A}$ and $1 \mathrm{~B}$ were present in rat and mouse brain MTs as well as in control mouse sciatic nerve. However, little or no phosphorylated MAP 1A could be detected in Trembler sciatic nerve. This suggested that MAP $1 \mathrm{~A}$ is present at normal levels in Trembler nerve, but is relatively less phosphorylated. Unfortunately, the mAb MAP 1B-4 does not recognize mouse MAP 1B in brain or sciatic nerve, although it clearly recognizes rat brain MAP $1 \mathrm{~B}$. The absence of immunoreactivity may indicate either a significant sequence divergence between rat and mouse, or a difference in folding or posttranslational modification that blocks the epitope. However, this precluded estimates of the relative amounts of MAP $1 \mathrm{~B}$ in control and Trembler nerve.

Quantitation of these differences in control and Trembler sciatic nerve MAPs was as described earlier for tau. As seen in Figure 7, there was a similar amount of MAP $1 \mathrm{~A}$ in Trembler and control sciatic nerves, but much less of the axonal MAP 1A is phosphorylated in the Trembler $(p=0.026$ by $t$ test using paired samples). The amount of phosphorylated MAP 1B was also apparently decreased in Trembler nerves $(p=0.008$ by $t$ test using paired samples). The difference in phosphorylated MAP 1B immunoreactivity indicates that either there is less MAP 1B in Trembler nerves, but no phosphorylation difference, or there is a comparable amount of MAP 1B that is less phos-

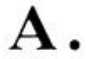

SILVER

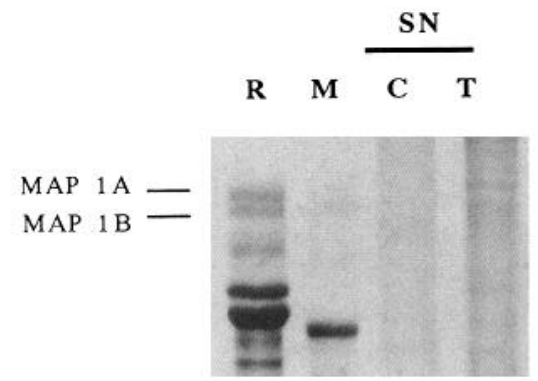

B.

\section{MAP 1A-2 MAP 1 B-3 MAP 1 B-4}
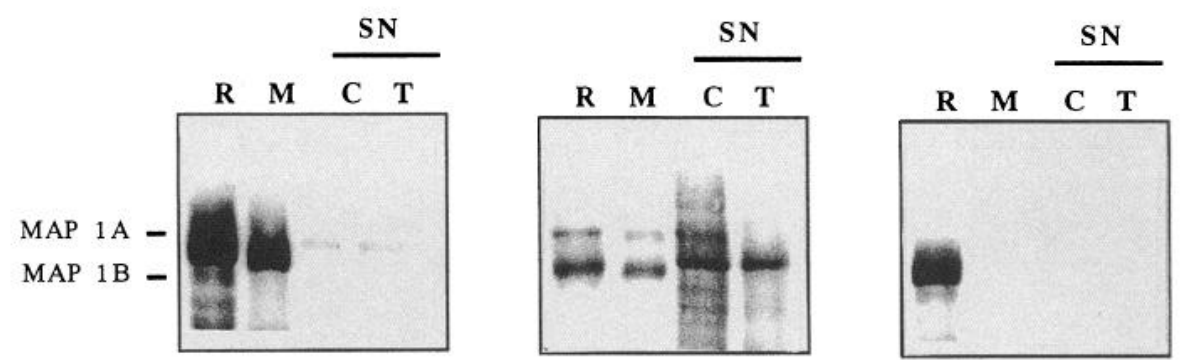

Figure 6. Immunoblot detection of HMW MAP proteins. $A$, High-molecular-weight region of a silver-stained $4 \%$ gel showing the samples used for analysis: rat $(R)$ and mouse $(M)$ brain MTs, $15 \mu \mathrm{g}$ each; control $(C)$ and Trembler $(T)$ mouse sciatic nerve, $15 \mu \mathrm{g}$. $B$, PhosphorImager image of immunoblots of these samples with three mAbs: MAP 1A-2 recognizes MAP 1A exclusively; MAP 1B-4 recognizes rat MAP 1B, but fails to recognize mouse MAP 1B; and MAP 1B-3 recognizes a phosphorylated epitope on both MAPs $1 \mathrm{~A}$ and 1B. There appeared to be no difference in the amount of immunoreactivity for total MAP $1 \mathrm{~A}$ in comparisons between control and Trembler sciatic nerve, but there was a difference in immunoreactivity against a phosphorylated epitope on both MAP 1A and MAP 1B. 
phorylated in Trembler nerves. Based on previous studies showing decreased NF phosphorylation in Trembler sciatic nerves and present results showing decreased MAP 1A phosphorylation, a reduction in MAP 1B phosphorylation appears most likely. Since there is immunochemical evidence for similarities between some phosphorylation sites on neurofilaments and HMW MAPs, similar kinase and phosphatase activities may act on both sets of cytoskeletal proteins. As with tau, blots of mouse optic nerve showed no difference between Trembler and control mice either in MAP $1 \mathrm{~A}$ concentration and phosphorylation, or in MAP 1B phosphorylation (data not shown). These experiments clearly demonstrated differences in the phosphorylation state of at least some HMW MAPs in Trembler demyelinated nerves, consistent with differences previously reported for neurofilaments (de Waegh et al., 1992).

Taken together, these experiments demonstrated that myelinating Schwann cells can dramatically alter the axonal MT cytoskeleton as well as axonal neurofilaments. Axonal MT stability and biochemical composition were both significantly altered by demyelination. Myelination has profound actions on the properties of both the MT and the NF cytoskeleton in peripheral nerve, effectively altering the functional architecture of the axon.

\section{Discussion}

A wide variety of functional domains can be identified in any neuron, ranging from perikarya to dendrites and axons to spines and presynaptic terminals. Each region has a characteristic morphology associated with its specific functions. Although specializations are readily recognized, relatively little has been known about how they are established and maintained in a particular location. Previous work in our laboratory on Trembler mouse axons established that myelinating Schwann cells exert a profound effect on axonal architecture (de Waegh and Brady, 1990, 1991; de Waegh et al., 1992).

The Trembler mouse is characterized by hypomyelination of peripheral axons, resulting from a mutation in a PNS-myelin protein (Suter et al., 1992). The morphology of axons surrounded by Trembler Schwann cells was severely altered, suggesting that myelinating glia modulate neuronal structure and function. Analysis of slow axonal transport in Trembler demonstrated that transport of NFs and some SCb proteins is slower in Trembler PNS neurons than in control mice (de Waegh and Brady, 1990). Electron microscopic studies demonstrated that the density of NFs in Trembler nerves is much higher than is seen in control nerves (de Waegh and Brady, 1991; de Waegh et al., 1992). Quantitative immunoblots using mAbs specific for phosphorylated and nonphosphorylated NFs showed that NFs in Trembler axons are deficient in phosphorylation. Changes in axonal parameters were local (de Waegh and Brady, 1991; de Waegh et al., 1992). When a segment of Trembler sciatic nerve was grafted into a normal nerve, only axon segments surrounded by Trembler Schwann cells exhibited the characteristic altered slow axonal transport, morphology, and NF phosphorylation of Trembler nerves.

These studies indicated that myelinating glia can modulate neuronal architecture. A simple model has been proposed to account for local control of axonal properties. Myelinating glia change NF density, and therefore axon caliber, by altering one or more kinase/phosphatase cycles within the axon. In regions surrounded by compact myelin, kinase activity is higher, NFs are more heavily phosphorylated, and, due to the repulsion from

\section{HMW MAP Immunoreactivity in Trembler and Control Mouse Sciatic Nerve}

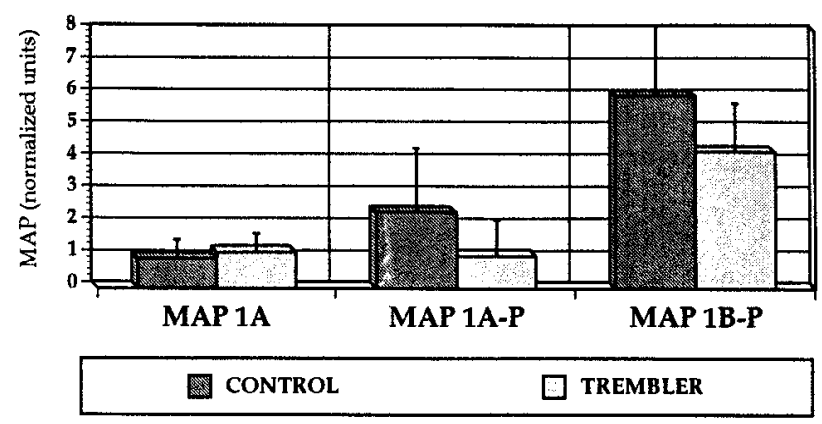

Figure 7. The phosphorylation but not the composition of HMW MAPs differs in Trembler sciatic nerve. The amount of radioactivity incorporated in each MAP was determined and normalized as described for tau. There was a significant difference between control and Trembler mouse sciatic nerves in the level of phosphorylation for MAPs 1A and $1 \mathrm{~B}$ (significantly different at $p<0.05$, using a $t$ test with paired samples) In contrast, the amount of MAP 1A relative to tubulin was not significantly different.

excessive negative charges, axonal caliber is larger. In demyelinated regions, phosphatase activity is higher, NFs are less phosphorylated, and, as a result, axon caliber is smaller (for a more detailed discussion of this model, see Brady, 1992; de Waegh et al., 1992).

Interactions between compact myelin and axon appear to be important for maturation of neurons as well. Regeneration rates are slower for Trembler sensory and motor neurons than for control neurons (de Waegh and Brady, 1990), yet initial outgrowth of transected axons occurs after a shorter delay in Trembler nerves. The overall pattern of regeneration in Trembler nerves appears similar to that of immature neurons, suggesting that the Trembler cytoskeleton may be functionally and biochemically immature (de Waegh and Brady, 1990). If this is true, then glia must be actively involved in normal axonal maturation.

In contrast to the slowing of most proteins in slow transport, axonal tubulin moved faster in Trembler axons (de Waegh and Brady, 1990). This observation suggested that axon-glial interactions during myelination may affect the axonal MT cytoskeleton as well as NFs. Three characteristics of the axonal MT cytoskeleton were evaluated in this study: the fraction of axonal MTs that is cold insoluble, the composition of axonal MAPs, and the phosphorylation state of axonal MAPs.

Previous studies demonstrated that axonal microtubules are enriched in a cold-insoluble form of tubulin (Brady et al., 1984) corresponding to cold-stable segments of microtubules (Sahenk and Brady, 1987). Slow axonal transport rates decrease in optic and sciatic nerves during aging (McQuarrie et al., 1989), while the amount of axonal tubulin in cold-insoluble fractions increases (Brady, 1984; Yan et al., 1985; Brady and Black, 1986), suggesting that generation of stable MTs is associated with maturation of the cytoskeleton. Thus, increases in cold-stable MTs appear to correlate with reduced plasticity and maturation of a neuron.

Neurons that retain the ability to regenerate in adulthood typically have tubulin moving with both $\mathrm{SCa}$ and $\mathrm{SCb}$ (McQuarrie et al., 1986; Oblinger et al., 1987). One difference between axonal microtubules in $\mathrm{SCa}$ and those in $\mathrm{SCb}$ is that $\mathrm{SCb}$ has a smaller proportion of cold-insoluble tubulin (Brady and 
Black, 1986). Increases in SCb tubulin noted in Trembler axons suggested that the amount of cold-insoluble tubulin was altered in Trembler axons. As seen in Figures 1 and 2, the amount of cold-insoluble tubulin in both $\mathrm{SCa}$ and $\mathrm{SCb}$ was reduced in Trembler nerves. Decreases in cold-stable MT fractions of Trembler axons are consistent with suggestions that Trembler nerves retain some immature characteristics.

The composition and properties of axonal MAPs were of interest for two reasons. First, MAP composition is cell type specific and developmentally regulated (Olmsted, 1986; Tucker, 1990), so an immature cytoskeleton may exhibit a different MAP composition. Sccond, MAPs are phosphoproteins in brain. The amount of phosphorylation and identity of phosphorylated epitopes modified on specific brain MAPs vary with both subcellular location and developmental stage. Since phosphorylation of axonal NFs was altered by demyelination, MAPs may also be affected.

Two heterogeneous groups of MAPs have been defined in nervous tissue: tau proteins and HMW MAPs. Tau proteins include low-molecular-weight (LMW), mid-molecular-weight (MMW), and high-molecular-weight (HMW) forms that may vary with region of the nervous system and development. Traditional LMW taus from adult brain consist of five or six proteins ranging in size from 50 to $70 \mathrm{kDa}$ on SDS gels (Cleveland et al., 1977). These proteins are generated from a single mRNA by alternative splicing (Lee et al., 1988; Kosik et al., 1989; Lee, 1990), with additional heterogeneity provided by phosphorylation (Peng et al., 1986; Papasozomenos and Binder, 1987; Butler and Shelanski, 1988). In rat, LMW taus are abundant in the CNS, but apparently absent in the PNS (Oblinger et al., 1991). LMW taus in Trembler peripheral nerve were notable, first because LMW tau were not found in the PNS of other species examined, and second because there was significantly more LMW tau in Trembler than in control nerves. This suggests that myelination may affect expression of cytoskeletal proteins, presumably through a retrograde signal to the cell body.

MMW (90-100 kDa) and HMW (110-120 kDa) taus have only recently been identified. MMW tau has so far been restricted to rat optic nerve (Taleghany and Oblinger, 1992), and its molecular origin is poorly understood. HMW tau proteins are also produced by alternative splicing from the same tau gene (Drubin et al., 1984; Neve et al., 1986; Oblinger et al., 1991; Couchie et al., 1992). HMW taus are abundant in PNS and scarce in CNS neurons (Drubin and Kirschner, 1986; Georgieff et al., 1991; Oblinger et al., 1991; Taleghany and Oblinger, 1992). HMW taus are thought to correlate with increased microtubule stability (Oblinger et al., 1991). The HMW tau population in Trembler sciatic nerve appears to consist of a single protein with an apparent molecular weight of $120 \mathrm{kDa}$. The level of this polypeptide is significantly decreased in demyelinated Trembler nerves, and its phosphorylation state may also be different in Trembler. These results indicate that the effects of myelination and demyelination on NF phosphorylation (de Waegh et al., 1992) extend to the MT cytoskeleton. Such changes are consistent with the reductions observed in MT stability reported here and the apparent immaturity of Trembler nerves seen in regeneration of Trembler axons (de Waegh and Brady, 1990). In agreement with studies in rat, MMW tau was found in mouse optic nerve, but not in sciatic nerve. Changes in tau composition and possibly phosphorylation suggest that functional alterations in the MT cytoskeleton of the axon occur following demyelination.
In contrast to tau MAPs, HMW MAPs are a diverse group of largely unrelated proteins, some found in a variety of tissues while others are brain specific (Olmsted, 1986; Matus, 1988; Tucker, 1990). All have apparent molecular weights greater than $300 \mathrm{kDa}$, appear to form sidearms protruding from the walls of MTs (Vallee and Davis, 1983), and may be involved in MT assembly and cytoskeletal organization (Vallee and Borisy, 1977). Five polypeptides comprise the HMW MAPs: MAPs 1A, 1B, $1 \mathrm{C}, 2 \mathrm{~A}$, and $2 \mathrm{~B}$. The MAP 2 complex of proteins appear closely related and are found primarily in dendrites (Kim et al., 1979; Miller et al., 1982). Three polypeptides known as MAP 1 represent unique proteins with no significant sequence homologies. MAP 1C is a cytoplasmic form of dynein (Paschal et al., 1987; Vallee et al., 1988). The effects of demyelination on MAP 2 and MAP 1C were not evaluated, because MAP 2 is effectively absent from axons (Caceres et al., 1983) and MAP 1C appears to be associated primarily with membrane-bound organelles in neurons (Hirokawa et al., 1990).

There is no sequence homology between MAPs $1 \mathrm{~A}$ and $1 \mathrm{~B}$ (Hammarback et al., 1991; Langkopf et al., 1992), and their distribution differs both during development and within neurons (Bloom et al., 1984, 1985). Immunological studies demonstrated that MAP $1 \mathrm{~B}$ is expressed during initial neuronal differentiation and neurite outgrowth (Bloom et al., 1985; Garner et al., 1990; Tucker, 1990), while MAP 1A is expressed later during stabilization of axons and dendrites (Bloom et al., 1985). Additional studies showed that MAP $1 \mathrm{~B}$ is differentially phosphorylated in different neuronal compartments during development. It is highly phosphorylated in growing axons, but unphosphorylated in cell bodies and dendrites (Sato-Yoshitake et al., 1989). This pattern is analogous to neurofilament phosphorylation patterns (Sternberger and Sternberger, 1983; Carden et al., 1987).

MAPs $1 \mathrm{~A}$ and $1 \mathrm{~B}$ in Trembler sciatic nerve appear to differ from control nerves only in phosphorylation. There were similar amounts of MAP 1A in both nerves, but it was significantly less phosphorylated in Trembler. Since most studies on MAP function and MAP distribution have focused on HMW MAPs in CNS tissue, relatively little information is available about the distribution and phosphorylation of MAPs in PNS tissue. The effects of dephosphorylated MAP 1A on MT assembly or spacing remain to be determined. Decreases in MAP 1A phosphorylation were consistent with decreases in NFH and NFM phosphorylation in Trembler nerves (de Waegh et al., 1992). Levels and phosphorylation state of MAP $1 \mathrm{~B}$ remain unclear. There was a significant difference in MAP 1B-3 immunoreactivity, due either to decreased amounts of MAP 1B protein, or to decreases in MAP 1B phosphorylation. Since levels of MAP 1B could not be determined with these antibodies, these two possibilities cannot be distinguished. Based on observed alterations in NF, tau, and MAP 1A phosphorylation, however, reductions in MAP 1B phosphorylation seem likely.

In summary, MTs in demyelinated Trembler peripheral nerves differ from those in control myelinated nerves in at least three ways. First, stability of Trembler MTs was decreased. Second, the composition and perhaps the phosphorylation of tau proteins were changed. Finally, phosphorylation of HMW MAPs was decreased. Further studies will be required to define the extent to which MT function may be altered, but these results provide evidence that cell-cell interactions exist between myelinating glia and axon that affect biochemical and physiological properties of the axonal cytoskeleton. Identifying metabolic 
pathways by which myelinating Schwann cells alter phosphorylation of axonal proteins will provide insights into mechanisms by which glia and neurons interact to create the functional architecture of the mature nervous system.

\section{References}

Aguayo A, Attiwell M, Trecarten J, Perkins S, Bray G (1977) Abnormal myelination in transplanted Trembler mouse Schwann cells. Nature 265:73-74.

Baas PW, Black MM (1990) Individual microtubules in the axon consist of domains that differ in both composition and stability. $J$ Cell Biol 111:495-509.

Binder LI, Frankfurter A, Rebhun LI (1985) The distribution of tau in the mammalian central nervous system. J Cell Biol 101:13711378.

Black MM, Baas PW, Humphries S (1989) Dynamics of $\alpha$-tubulin deacetylation in intact neurons. J Neurosci 9:358-368.

Bloom GS, Schoenfeld TA, Vallee RB (1984) Widespread distribution of the major polypeptide component of MAP 1 (microtubule associated protein 1) in the nervous system. J Cell Biol 98:320-330.

Bloom GS, Luca FC, Vallee RB (1985) Microtubule-associated protein 1B: identification of a major component of the neuronal cytoskeleton. Proc Natl Acad Sci USA 82:5404-5408.

Blum H, Beier H, Gross HJ (1987) Improved silver-staining of plant proteins, RNA, and DNA in polyacrylamide gels. Electrophoresis 8:93-99.

Brady ST (1984) Increases in cold-insoluble tubulin during aging. Soc Neurosci Abstr 10:273.

Brady S (1985) Axonal transport methods and applications. In: Neuromethods, general neurochemical techniques (Boulton A, Baker $\mathrm{G}$, eds), pp 419-476. Clifton, NJ: Humana.

Brady ST (1988) Cytotypic specializations of the neuronal cytoskeleton and cytomatrix: implications for neuronal growth and regeneration. In: Cellular and molecular aspects of neural development and regeneration (Haber B, Gorio A, Vellis JD, Perez-Polo JR, eds), pp 311322. New York: Springer.

Brady ST (1992) Axonal dynamics and regeneration. In: Neuroregeneration (Gorio A, ed), pp 7-36. New York: Raven.

Brady ST, Black MM (1986) Axonal transport of microtubule proteins: cytotypic variation of tubulin and MAPs in neurons. Ann NY Acad Sci 466:199-217.

Brady ST, Tytell M, Lasek RJ (1984) Axonal tubulin and axonal microtubules: biochemical evidence for cold stability. J Cell Biol 99: 1716-1724.

Butler M, Shelanski M (1988) Microheterogeneity of microtubule associated tau proteins is due to differences in phosphorylation. J Neurochem 47:1517-1522.

Caceres A, Payne MR, Binder LI, Steward O (1983) Immunocytochemical localization of actin and microtubule-associated protein (MAP2) in dendritic spines. Proc Natl Acad Sci USA 80:1738-1742.

Caceres A, Binder LI, Payne MR, Bender P, Rebhun L, Steward O (1984) Differential subcellular localization of tubulin and microtubule associated protein MAP2 in brain tissue as revealed by immunocytochemistry with monoclonal hybridoma antibodies. J Neurosci 4:394-410.

Carden MJ, Trojanowski JQ, Schlaepfer WW, Lee VM-Y (1987) Two stage expression of neurofilament polypeptides during rat neurogenesis with early establishment of adult phosphorylation patterns. $J$ Neurosci 7:3489-3504.

Cleveland D, Hwo SY, Kirshner MW (1977) Purification of tau, a microtubule associated protein that induces assembly of tubulin from purified tubulin. J Mol Biol 116:207-225.

Couchie D, Mavilla C, Georgieff IS, Liem RK, Shelanski ML, Nunez J (1992) Primary structure of high molecular weight tau present in the peripheral nervous system. Proc Natl Acad Sci USA 89:43784381 .

de Waegh S, Brady ST (1990) Altered slow axonal transport and regeneration in a myelin deficient mutant mouse: the Trembler mouse as an in vivo model for Schwann cell-axon interactions. J Neurosci 10:1855-1865.

de Waegh SM, Brady ST (1991) Local control of axonal properties: neurofilaments and axonal transport in homologous and heterologous nerve grafts. J Neurosci Res 30:201-212.

de Waegh SM, Lee VM-Y, Brady ST (1992) Local modulation of neurofilament phosphorylation, axonal caliber, and slow axonal transport by myelinating Schwann cells. Cell $68: 451-463$.

Drubin D, Kirschner M (1986) Tau protein function in living cells. J Cell Biol 103:2739-2746.

Drubin DG, Caput D, Kirschner MW (1984) Studies on the expression of the microtubule-associated protein, tau, during mouse brain development, with newly isolated complimentary DNA probes. J Cell Biol 98:1090-1097.

Edde B, Rossier J, LeCaer J-P, Desbruyeres E, Gros F, Denoulet P (1990) Posttranslational glutamylation of alpha tubulin. Science 247: 83-85.

Gard DL, Kirschner M (1985) A polymer dependent increase in phosphorylation of $\beta$-tubulin accompanies differentiation of a mouse neuroblastoma cell line. J Cell Biol 100:764-774.

Garner CC, Garner A, Huber G, Kozak C, Matus A (1990) Molccular cloning of MAP $1 \mathrm{~A}$ and MAP 5 (MAPIB): identification of distinct genes and their differential expression in developing brain. $J$ Neurochem 55:146-154.

Georgieff I, Liem R, Mellado W, Nunez J, Shelanski M (1991) High molecular weight tau: preferential localization in the peripheral nervous system. J Cell Sci 100:55-60.

Gillespie PG, Hudspeth AJ (1991) Chemiluminescence detection of proteins from single cells. Proc Natl Acad Sci USA 88:2563-2567.

Hammarback JA, Obar RA, Hughes SM, Vallee RB (1991) MAP IB is encoded as a polyprotein that is processed to form a complex N-terminal microtubule-binding domain. Neuron 7:129-139.

Hirokawa N, Yoshida Y, Sato-Yoshitake R, Kawashima T (1990) Brain dynein (MAP1C) localizes on both anterogradely and retrogradely transported membranous organclles in vivo. J Cell Biol 111:10271037.

Khawaja S, Gunderson GG, Bulinski JC (1988) Enhanced stability of microtubules enriched in detyrosinated tubulin is not a direct function of detyrosination level. J Cell Biol 106:141-150.

Kim H, Binder L, Rosenbaum JL (1979) The periodic association of MAP2 with brain microtubules in vitro. J Cell Biol 80:266-276.

Kosik KS, Orecchio LD, Bekalis S, Neve RL (1989) Developmentally regulated expression of specific tau sequences. Neuron 2:1389-1397.

Langkopf A, Hammarback JA, Muller R, Vallee RB, Garner CC (1992) Microtubule associated proteins $1 A$ and LC2. J Biol Chem 267:1656116566.

Lee $G$ (1990) Tau protein: an update on structure and function. Cell Motil Cytoskel 15:199-203.

Lec G, Cowan N, Kirschner M (1988) The primary sequence and heterogeneity of tau protein from mouse brain. Science 239:285-288.

Lewis SA, Lee MG, Cowan NJ (1985) Five mouse tubulin isotypes and their regulated expression during development. J Cell Biol 101: 852-861.

Luca FC, Bloom GS, Vallee RB (1986) A monoclonal antibody that cross-reacts with phosphorylated epitopes on two microtubule-associated proteins and two neurofilament polypeptides. Proc Natl Acad Sci USA 83:1006-1010.

Luduena RF (1993) Are tubulin isotypes functionally significant? Mol Biol Cell 4:445-447.

Matus A (1988) Microtubule-associated proteins: their potential role in determining neuronal morphology. Annu Rev Neurosci 11:29-44.

McQuarrie IG, Brady ST, Lasek RJ (1986) Diversity in the axonal transport of structural proteins: major differences between optic and spinal axons in the rat. J Neurosci 6:1593-1605.

McQuarrie IG, Brady ST, Lasek RJ (1989) Retardation in axonal transport of cytoskeletal elements during maturation and aging. Neurobiol Aging 10:359-365.

Miller P, Walter U, Theurkauf E, Vallee RB, de Camilli P (1982) Frozen tissue sections as an experimental system to reveal specific binding sites for the regulatory subunit of type II cAMP-dependent protein kinase in neurons. Proc Natl Acad Sci USA 79:5562-5566.

Murata H, Green K, Rosenbaum JL (1986) The acetylation of alphatubulin and its relationship to the assembly and disassembly of microtubules. J Cell Biol 103:571-579.

Neve RL, Harris P, Kosik KS, Kurnit DM, Doulon TA (1986) Identification of cDNA clones for the human microtubule-associated protein tau and chromosomal localization of the genes for tau and microtubule-associated protein 2. Mol Brain Res 1:272-280.

Oblinger MM, Brady ST, McQuarrie IG, Lasek R (1987) Differences in the protein composition of the axonally transported cytoskeleton in peripheral and central mammalian neurons. J Neurosci 7:453-462. 
Oblinger MM, Argasinski A, Wong J, Kosik KS (1991) Tau gene expression in DRG neurons during development and regeneration. $\mathrm{J}$ Neurosci 11:2453-2459.

Olmsted J (1986) Microtubule associated proteins. Annu Rev Cell Biol 2:421-457.

Papasozomenos SC, Binder LI (1987) Phosphorylation determined two distinct species of tau in the central nervous system. Cell Motil Cytoskel 8:210-226.

Paschal BM, Shpetner HS, Vallee RB (1987) MAP1C is a microtubuleactivated ATPase which translocates microtubules in vitro and has dynein-like properties. J Cell Biol 105:1273-1282.

Peng I, Binder L, Black MM (1986) Biochemical and immunological analysis of cytoskeletal domains of neurons. J Cell Biol 102:252-262.

Sahenk Z, Brady ST (1987) Axonal tubulin and axonal microtubules: morphologic evidence for stable regions on axonal microtubules. Cell Motil Cytoskel 8:155-164.

Sato-Yoshitake R, Shiomura Y, Miyasaka H, Hirokawa N (1989) MAP 1B: molecular structure, localization, and phosphorylation-dependent expression in developing neurons. Neuron 3:229-238.

Sternberger L, Sternberger N (1983) Monoclonal antibodies distinguish phosphorylated and nonphosphorylated forms of neurofilaments in situ. Proc Natl Acad Sci USA 80:6126-6130.

Sullivan KF (1988) Structure and utilization of tubulin isotypes. Annu Rev Cell Biol 4:687-716.
Suter U, Welcher AA, Ozcelik T, Snipes GJ, Kosaras B, Francke U, Billings-Gagliardi S, Sidman RL, Shooter EM (1992) Trembler mouse carries a point mutation in a myelin gene. Nature 356:241-243.

Taleghany N, Oblinger MM (1992) Regional distribution and biochemical characteristics of high molecular weight tau in the nervous system. J Neurosci Res 33:257-265.

Tucker RP (1990) The roles of microtubule associated proteins in brain morphogenesis: a review. Brain Res Rev 15:101-120.

Vallee RB (1982) A taxol-dependent procedure for the isolation of microtubules and microtubule-associated proteins. J Cell Biol 92: $435-442$.

Vallee RB, Borisy GG (1977) Removal of the projections from cytoplasmic microtubules in vitro by digestion with trypsin. J Biol Chem 252:377-382.

Vallee RB, Davis SE (1983) Low molecular weight microtubule associated proteins are light chains of microtubule-associated protein 1 (MAP1). Proc Natl Acad Sci USA 80:1342-1346.

Vallee RB, Wall JS, Paschal BM, Shpetner HS (1988) Microtubule associated protein $1 \mathrm{C}$ from brain is a two headed cytosolic dynein. Nature 332:561-563.

Yan SB, Hwang S, Rustan TD, Frey WH (1985) Human brain tubulin purification: decrease in soluble tubulin with age. Neurochem Res 10: $1-18$. 